Комнатний Сергій Олександрович кандидат педагогічних наук, Національна академія внутрішніх справ, Солом'янська площа, 1, м. Київ, 02000, e-mail: komnatniy@ukr.net, тел.: (095) 280-24-80, https://orcid.org/00000002-2124-2047

\title{
ТЕОРЕТИЧНІ НАРОБКИ АНАЛІЗУ ЗМІСТУ ЖИТЛОВОЇ ПОЛІТИКИ
}

Анотація. Житлова політика будь-якої держави складає базу засобів і механізмів, покликаних забезпечити базову потребу людини у достойному житлі. Житлова політика є однією зі складових соціальної політики держави, але, враховуючи іiі значення та зміст, зазвичай вона реалізовується як окрема галузь політики. Зміст житлової політики визначається основними векторними нормативно-правовими актами, такими як Конституція, концепція чи стратегія. Враховуючи актуальність даного дослідження, що підтверджується численними науковими роботами 3 відповідної теми і фактичною наявністю комплексу нерозв'язаних проблем у галузі житлового забезпечення, теорію змісту житлової політики можна віднести до окремої галузі науки, яка потребує опрацювання на науковому рівні. Житлова політика, окрім соціальної складової, у своїй суті має і складову економічну. Перед державами стоїть завдання розробляти і впроваджувати такі житлові політики, в яких буде збалансовано міру соціальної відповідальності суб'єктів та економічні вигоди від іiї впровадження, при цьому соціальноекономічна житлова політика має бути справедливою і зрозумілою. В іншому разі це може призвести до непорозумінь між владою і суспільством, викривлення сприйняття меж відповідальності та встановлення нерівностей.

У даній статті проведено аналіз змісту житлової політики України, досліджено іï напрями, визначено суб'єкт, об'єкт і мету державної житлової політики держави. Розглянуто теоретичні і практичні проблеми формування, становлення і функціонування систем забезпечення реалізації соціальноорієнтованої житлової політики нашої держави. Проаналізовано взаємозалежний соціальний і економічний ефект впровадження механізмів житлової політики. Проведено аналіз нормативно-правових актів, юридичної літератури і наукових досліджень, які дають визначення житлової політики і житла. Проаналізовано основні чинні нормативні акти у сфері житлової політики і деякі розроблені проєкти.

Невідповідності теоретичних постулатів практичним аспектам, виявлені під час дослідження, вказують на необхідність подальшого наукового опрацювання аналізу змісту житлової політики.

Ключові слова. Житлова політика, концепція житлової політики, житлова стратегія, соціальне житло, житло, механізми забезпечення житлом, житловий фонд. 
Komnatniy Serhii Oleksandrovych $\mathrm{PhD}$ in Pedagogical Sciences, National Academy of Internal Affairs, Solomianska Square, 1, Kyiv, 02000, tel.: (095) 28024-80, e-mail: komnatniy@ukr.net, https://orcid.org/0000-0002-2124-2047

\section{THE ORETICAL DEVELOPMENTS IN THE ANALYSIS OF THE CONTENT OF HOUSING POLICY}

Abstract. The housing policy of any country forms the basis of means and mechanisms designed to meet the basic human need for adequate housing. Housing policy is one of the components of the country's social policy, but, given its significance and content, it is usually implemented as a separate branch of policies. The content of housing policy is determined by fundamental vector regulations, such as the Constitution, concept or strategy. Given the relevance of this study, which is confirmed by numerous scientific papers on the subject and the actual existence of a set of unresolved issues in the field of housing, the theory of housing policy can be attributed to a separate field of science that needs to be studied at the scientific level. Housing policy, in addition to the social component, in essence has an economic component. The task of countries is to develop and implement housing policies that will balance the degree of social responsibility of entities and the economic benefits of its implementation, while socio-economic housing policy must be fair and understandable. Otherwise, it can lead to misunderstandings between government and society, distort the perception of the limits of responsibility and lead to inequalities.

This article analyzes the content of the housing policy of Ukraine, studies its directions, defines the subject, object and goals of the national housing policy of the country. Considers the theoretical and practical problems of the formation, establishment and functioning of systems for ensuring the implementation of the socially oriented housing policy of our country. Analyses the social and economic effect of the implementation of housing policy mechanisms. In addition, the analysis of normative legal acts, legal literature and scientific research, which define the housing policy and housing, is carried out. The main existing regulations in the field of housing policy and some developed projects are analyzed.

The inconsistencies of the theoretical postulates with the practical aspects revealed during the research indicate the need for further scientific elaboration of the analysis of the content of housing policy.

Keywords: Housing policy, concept of the housing policy, housing strategy, social housing, housing, housing mechanisms, housing fund.

Постановка проблеми. Проблема забезпечення права на житло як основного 3 природних прав людини турбує уряди всіх держав світу. Зазначену проблему можна вирішити лише шляхом впровадження соціальноорієнтованої, економічно збалансованої державної житлової політики. Житлова політика української держави вже тридцять років перебуває у процесі трансформації від соціалістичних до ринкових житлових систем. 
Нормативна база, яка регулює сферу житлової політики, є застарілою, містить колізії, не відповідає сучасним реаліям. Вектор розвитку державної житлової політики, затверджений Конституцією України i Концепцією державної житлової політики, не знайшов повного практичного відображення, тобто не досягнуто системних практичних результатів. Для забезпечення рівного доступу громадян до житла і встановлення в Україні соціальних стандартів Ради Свропи необхідно на науковому і законодавчому рівні опрацювати проблему та розробити ефективні механізми реалізації житлової політики.

Аналіз останніх досліджень і публікацій. Теоретичні і практичні аспекти житлової політики на науковому рівні досліджували такі українські й закордонні вчені, як О. Непомнящий, О. Кучеренко, В. Ніколаєв, B. Кравченко, А. Шушківський, Habermas J., Wolfgang Kiehle, Jean-Claude Driant, Edyty Masierek та інші.

Мета статті. Метою статті $є$ вивчення і дослідження теоретичних аспектів реалізації житлової політики та аналіз їі змісту.

Методологічний інструментарій обрано з урахуванням поставленої мети, специфіки предмета й об'єкта дослідження через системний порівняльноправовий аналіз чинних нормативних актів в галузі, дослідження якості, результатів і ефективності їхнього впровадження.

Виклад основного матеріалу. Нормативно-правові акти, які формують систему житлової політики держави і складають юридичну базу парадигми природного права людини на житло, є своєрідними регуляторами правової взаємодії у комунікаціях суб’єктів житлової політики. Спрямованість цієї правової комунікації має культурно-релевантний характер, змінюється разом iз трансформацією суспільно-правової дійсності та $є$ соціальним процесом. Такі соціально-правові комунікації мають спиратися на індивідуальну i колективну свідомість як похідну національної правосвідомості, що виникає внаслідок генерування історико-культурних і суспільно-політичних процесів державотворення. Становлення демократичних засад буття суспільства i державотворення, безперечно, залежить від якості соціально-правових комунікацій. Безперервний системний аналіз процесів соціально-правових комунікацій, їх системна і своєчасна модернізація відповідно до стандартів Ради Свропи є запоруками розвитку демократичного суспільства в Україні та Свроінтеграційного курсу нашої держави. Забезпечення і захист природних прав людини, в тому числі житлових, є одним з важливих аспектів соціальноправової комунікації.

Житло як позитивне право, яке базується на природних началах, слід розглядати як необхідність чи потребу з точки зору розвитку як онтологічних так і гносеологічних ознак еволюції людини і суспільства в цілому.

Для розкриття сутності поняття житлової політики i аналізу іï змісту необхідно визначити суб'єкт, об'єкт житлової політики і мету їі реалізації. Отже, суб’єктами державної житлової політики є громадяни, органи влади всіх рівнів і установи, метою діяльності яких є впровадження заходів у галузі житлової політики; об’єктом є безпосередньо житло; метою впровадження 
державної житлової політики є забезпечення права суб'єкта (громадянина) на об'єкт (житло).

Юридичне визначення поняття "житло" встановлене Цивільним кодексом України як об'єкт права власності чи іншого титульного права. У постанові Пленуму Верховного Суду України "Про судову практику в справах про корисливі злочини проти приватної власності" від 25.12.92 р. N 12 у п. 30 наводилося таке визначення житла: "...приміщення, яке призначене для постійного чи тимчасового проживання людей (приватний будинок, квартира, кімната в готелі, дача, садовий будинок тощо), а також ті його складові частини, які використовуються для відпочинку, зберігання майна або задоволення інших потреб людини (балкони, веранди, комори тощо)". Як випливає із цього визначення, під житлом малося на увазі будь-яке приміщення, призначене для проживання людини (в тому числі тимчасового) та забезпечення іiі потреб [1].

Загалом в українській мові термін "житло" означає приміщення, призначене для життя людей, або місце для перебування та проживання людей [2].

У юридичній літературі житло розглядається 3 кількох точок зору. Поперше, як місце проживання особи, по-друге, як об'єкт права власності. Незалежно від того, з якої точки зору воно розглядається, житло має низку спільних ознак. Першою 3 них $є$ призначення для проживання в ньому людини, що засвідчує приналежність житла до житлового фонду України. Відповідно до ст. 4 Житлового кодексу УРСР, житловий фонд утворюють жилі будинки, а також жилі приміщення в інших будівлях, що знаходяться на території України. При цьому не входять до житлового фонду нежилі приміщення в жилих будинках, призначені для торговельних, побутових та інших потреб непромислового характеру. Відповідно до тієї ж ст. 4 Житлового кодексу УРСР, житловий фонд включає: жилі будинки і жилі приміщення в інших будівлях, що належать державі (державний житловий фонд); жилі будинки і жилі приміщення в інших будівлях, що належать кооперативним організаціям, їх об'єднанням, профспілковим та іншим громадським організаціям (громадський житловий фонд); жилі будинки, що належать житлово-будівельним кооперативам (фонд житлово-будівельних кооперативів); жилі будинки (частини будинків), квартири, що належать громадянам на праві приватної власності (приватний житловий фонд); квартири в багатоквартирних жилих будинках, садибні (одноквартирні) жилі будинки, а також жилі приміщення в інших будівлях усіх форм власності, що надаються громадянам, які відповідно до закону потребують соціального захисту (житловий фонд соціального призначення) [3].

В. І. Кравченко у своєму дослідженні «Житлова економіка України» дає визначення житлу як місцю існування і перебування людини як біологічної істоти, що оберігає іiі від зовнішніх сил, середовищу для існування сім’і, народження дітей, відпочинку, сну, освіти, духовного розвитку, відтворення робочої сили [4].

Доступ до житла як базової потреби і умови розвитку суспільства 
забезпечується через інструменти житлової політики.

Житлова політика є невід'ємною складовою соціально-економічної політики держави, спрямованою на забезпечення права людини на гідне життєве середовище з високою якістю і комфортністю проживання [5].

Основоположним документом, який визначає стратегію державної житлової політики України, є схвалена Верховною Радою України 1995 року «Концепція державної житлової політики» [6]. Незважаючи на те, що цей документ не новий і був прийнятий ще до ухвалення Конституції України та ратифікації Україною низки міжнародних актів у сфері захисту прав громадян, більшість положень Концепції не втратили актуальності досьогодні. Можливо, певною мірою через те, що задекларовані Концепцією постулати не були повноцінно упроваджені на практиці. Концепція визначає проблеми в галузі житлової політики, а саме: недосконалість фінансовокредитної системи, централізація будівництва, реконструкції та утримання житлового фонду, обмеження у виділенні земельних ділянок і спорудженні індивідуального житла, відсутність стимулюючих факторів у вирішенні житлових питань значно загострили житлову проблему. Водночас, попри низький рівень забезпеченості громадян житлом, обсяги житлового будівництва щорічно зменшуються. До того ж потребують докорінної зміни чинні законодавчі й інші нормативні акти, що регулюють відносини у житловій сфері.

Концепція визначає напрямки, у яких має формуватися і реалізовуватися державна житлова політика, а саме:

- створення умов, за яких кожний громадянин вільно, на свій вибір, відповідно до своїх потреб і можливостей зміг би спорудити житло, придбати його у власність, узяти в оренду;

- забезпечення житлом за рахунок держави у межах встановленої норми соціально незахищених громадян, які потребують поліпшення житлових умов, зокрема, малозабезпечених, інвалідів, ветеранів війни, військовослужбовців, осіб, які постраждали внаслідок аварії на Чорнобильській AEC, та деяких інших категорій громадян, визначених Житловим кодексом України та іншими законодавчими актами;

- надання житла із державного житлового фонду або субсидій, пільгових кредитів для придбання чи спорудження житла сім'ям, які тривалий час перебувають на квартирному обліку, з урахуванням строку перебування на черзі та їхнього матеріального стану. Сприяння молодим сім'ям у спорудженні або придбанні житла;

- стимулювання державою будівництва, реконструкції та утримання житла через систему економічних і фінансових важелів;

- зміна стратегії містобудування у напрямку розширення обсягів спорудження більш комфортного житла, малоповерхових будинків садибного типу, розвитку малих і середніх населених пунктів. Створення сприятливого життєвого середовища із необхідною інфраструктурою соціально-побутового і культурного обслуговування населення;

- ліквідація ветхого і аварійного державного житлового фонду, активна 
реконструкція і модернізація житлового фонду старої забудови, розселення квартир, у яких мешкають двоє або більше наймачів;

- сприяння зростанню обсягів будівництва, поліпшенню якості й підвищенню рівня благоустрою житла у сільських населених пунктах, невідкладне створення житлово-комунальної служби в селах;

- подальший, у міру реформування заробітної плати, перехід на самоокупну систему плати за користування житлом і комунальні послуги і до адресних субсидій на ці витрати малозабезпеченим та соціально незахищеним сім'ям;

- поступовий, у міру проведення економічних реформ, перерозподіл функцій між органами державної виконавчої влади, місцевого самоврядування, підприємствами, установами i організаціями у сфері будівництва, реконструкції та утримання житла 3 метою їх децентралізації.

Концепція визначає мету державної житлової політики, яка полягає у створенні умов для реалізації права громадян на житло, розширенні житлового будівництва, поліпшенні утримання та збереження житлового фонду. Ефективна державна житлова політика повинна мати дві основні складові: соціальну і економічну. Перша полягає в забезпеченні реалізації громадянами права на житло. При цьому необхідно розробляти i впроваджувати механізми запобігання появі нерівностей чи дискримінації окремих груп населення в їхньому доступі до достатнього, доступного i достойного житла. Розробка і впровадження соціально-орієнтованої житлової політики має відбуватися 3 урахуванням специфіки регіонів, історичних i культурних аспектів та відповідати світоглядним очікуванням громадян. Економічна складова має базуватися на розвитку галузі будівництва житла 3 урахуванням балансу реальної потреби i економічної спроможності майбутніх користувачів відповідним житловим фондом. Житло має бути доступним за ціною як на момент його придбання чи оренди, так і в період експлуатації. При проектуванні і будівництві або реконструкції житла слід використовувати інноваційні підходи 3 метою зменшення впливу на екологію i скорочення споживання енергоресурсів. Факти свідчать про економічний вплив будівельної галузі на показники розвитку економіки країни в цілому, тож збільшення обсягів будівництва житла, окрім соціального ефекту, забезпечує позитивний вплив на економіку держави.

Як у країнах Європи, так і в Україні державна житлова політика $є$ важливим чинником економічного розвитку. Такий вплив здійснюється опосередковано - через роботу будівельної галузі. Будівельна галузь є однією 3 найбільш економікоємних галузей, каталізатором розвитку суміжних галузей - виробництва будівельних матеріалів, предметів побутової потреби, надання послуг із будівельно-монтажних робіт, адміністрування житлового фонду і торгівлі тощо.

Правильна i збалансована державна житлова політика має надавати поштовх розвитку будівельної і суміжних галузей. У період кризових явищ в економіці будівельна галузь першою відчуває їхні наслідки і найважче з неї виходить. Отже, державна житлова політика на сучасному етапі розвитку 
нашої держави також має бути орієнтованою на економічний захист будівельної галузі. Одним з прикладів такого захисту є прийнятий 2009 року Закон України №800 «Про запобігання впливу світової економічної кризи на будівельну галузь», який передбачає низку заходів які мали би зберегти економічний потенціал галузі й створити можливості для іiі розвитку, що позитивно вплинуло б на суміжні галузі та економіку країни загалом. Цей закон, можливо, дещо модернізований, зможе ефективно вплинути на сучасну житлову політику нашої країни.

Проведення активної, соціально орієнтованої державної житлової політики також дасть змогу вирішити одну 3 найбільш актуальних задач у сфері державної житлової політики - розширення платоспроможного попиту на послуги будівельної галузі.

Державна житлова політика - це комплекс заходів, які регламентуються державою і визначають основні напрямки реалізації прав громадян на житло. Державна житлова політика сучасної України дуже неоднозначна. 3 одного боку, маємо задекларовані нормативно-правові можливості забезпечення житлом громадян і розвитку будівельної галузі як одного з реальних секторів економіки. 3 іншого - спостерігаємо дуже обмежені можливості для їхньої реалізації. Нормативна база сформована із законів, кодексів і постанов, ухвалених у різний час. Вони почасти суперечать один одному. Житловий кодекс діє ще з часів УРСР, правила взяття на квартирний облік морально, соціально й економічно застарілі, в час прийняття цих документів в Україні не було поняття ринкової економіки тож вони не можуть бути спрямовані на створення умов для самостійного розвитку галузі будівництва.

Теоретично правильні, але часто невиконувані на практиці декларативні акти продовжують ухвалюватися в Україні. До прикладу, це Закон України «Про житловий фонд соціального призначення», який діє 31 січня 2007 року. Поняття «соціальне житло» у нашому суспільстві викликає різне сприйняття і тлумачення. Соціальними назвали квартири, які громадяни, що перебувають на обліку для поліпшення житлових умов, отримували в постійне користування. Зазначений Закон називає соціальним також житло, яке надаватиметься малозабезпеченим родинам у тимчасове користування. В розумінні забудовників соціальне житло - це будинки найбільш дешевого класу (квартири в яких, тим не менше, продаються всім охочим за вільними ринковими, а не соціальними цінами).

У більшості країн житлова політика $є$ однією 3 найбільш значущих галузей публічної політики, найбільш гострих і постійних тем громадських дискусій. У багатьох країнах формування i використання державного i муніципального житла, $\epsilon$ ключовим напрямом реалізації соціальноорієнтованої житлової політики, оскільки це найбільш енергійна форма державного втручання у функціонування житлового ринку. У нас же 3 початком приватизації цей вектор із поля житлової політики зник. Необхідного фонду державного i муніципального житла в Україні не залишилося, нові фонди практично не створюються.

Спроба законодавчого визначення поняття, суті й принципів державної 
житлової політики України була здійснена 2009 року, коли було розроблено і зареєстровано Проєкт Закону України «Про засади державної житлової політики» №4676, який, однак, не був ухвалений Верховною Радою України. Цей законопроєкт встановлював визначення державної житлової політики як системи взаємопов'язаних послідовних дій держави, спрямованих на створення умов, за яких громадяни матимуть змогу побудувати житло, придбати його у власність, наймати, а ті, що потребують соціального захисту, отримати житло безоплатно або за доступну ціну від держави чи територіальної громади. Державна житлова політика $\epsilon$ невід'ємною складовою соціально-економічної політики України, спрямованою на підвищення добробуту іiі громадян як однієї з умов забезпечення соціальноекономічного розвитку країни. Метою державної житлової політики $\epsilon$ створення економічних, соціальних i правових умов для реалізації громадянами конституційного права на житло. Держава визначає пріоритети, форми і засоби своєї участі в реалізації громадянами конституційного права на житло виходячи із загальносуспільних інтересів та економічних можливостей. Основними принципами державної житлової політики є: рівність прав громадян у виборі способу реалізації конституційного права на житло; доступність житла громадянам відповідно до їх фінансових можливостей, державних соціальних гарантій та соціальних гарантій, визначених органами місцевого самоврядування; прогнозування напрямів, заходів та способів задоволення житлових потреб громадян; етапність задоволення житлової потреби громадян відповідно до Загальнодержавної житлової програми, державних цільових та регіональних програм; системність задоволення житлової потреби громадян 3 урахуванням соціальних, економічних, містобудівних, технічних, демографічних, екологічних та регіональних умов; децентралізованість управління приватним житловим фондом та надання житлово-комунальних послуг; державний контроль за технічним станом житлового фонду, ефективністю управління ним та його використанням незалежно від форми власності; публічність у вирішенні питань розроблення та реалізації державної житлової політики, використанні коштів державного та місцевих бюджетів, обговоренні проектів нормативно-правових актів 3 питань державної житлової політики.

Державні програми розвитку житлового будівництва практично завжди були найважливішою складовою частиною загальнодержавних програм виходу з економічних криз різних країн у різні часи. Пов'язано це $з$ тим, що житловий ринок має специфічні характеристики, які визначають його особливе місце в економічному механізмі та $\epsilon$ причиною високого мультиплікативного ефекту інвестицій у житлове будівництво. Сильний мультиплікативний ефект житлових інвестицій пояснюється кількома причинами: по-перше, житлове будівництво має великий коефіцієнт взаємозв'язку 3 іншими галузями економіки, що веде до негайного підвищення попиту в низці галузей; по-друге, придбання житла призводить до різкого збільшення попиту на супутні товари, тобто відбувається 
зростання граничної схильності до споживання; по-третє, у результаті придбання житла виявляються залученими до економічного обігу заощадження домашніх господарств.

Аналіз реалізації державних цільових програм виявив низку суттєвих проблем. Постійне недофінансування призвело до розпорошення бюджетних коштів, i, як наслідок, до недосягнення визначених цілей.

Нормативно правове забезпечення, що регулює загальні засади реалізації житлової політики в Україні, в тому числі житлових програм, $є$ доволі застарілим і потребує вдосконалення. Система нормативно-правових актів, які регулюють питання реалізації житлових програма $є$ розгалуженою та несистематизованою. Пересічному користувачу важко розібратися в існуючій пропозиції житлових програм та умовах їх реалізації. Питання потребує системного вирішення, можливо, ухвалення єдиного нормативноправого акту, закону.

Така позиція неодноразово ініціювалася народними депутатами України останніх скликань, проте максимальний результат, якого було досягнуто, - це прийняття таких законів у першому читанні (до прикладу, проєкт Закону України «Про особливості державної підтримки забезпечення молоді житлом»).

Заплановані соціально-економічні показники реалізації державних житлових програм за умови фактичного їх досягнення можуть мати реальний влив на поліпшення соціального добробуту населення, розвиток будівельної галузі країни, а відповідно, і економіки країни загалом.

Фінансування державних житлових програм у запланованих обсягах дасть змогу залучити додаткові інвестицій у будівельну галузь, яка $\epsilon$ системоутворюючою в національній економіці, позитивно вплине на розвиток економіки України загалом.

Житлова політика держави являє собою програму i практичне iii виконання, спрямоване на забезпечення функціонування середовища, в якому стабільно i економічно ефективно відбувається оборот житлового фонду, в межах дії якого задовольняються житлові потреби громадян, визначені державою i відповідними міжнародними актами. Розвиток стандартів будівництва житла у напрямку якості, належне підтримання i реконструкція житла забезпечують поштовх іншим складовим економіки держави. Окрім фінансового і організаційного характеру, вектор дії житлової політики держави має бути спрямований на вирішення питань соціального характеру[7].

Будь-яка державна політика, в тому числі житлова, базується i формується на основі сукупності загальних принципів, які адекватно відображають основні життєві потреби та інтереси людини і формують філософсько-правові засади права людини на житло.

За жодних умов житлова політика розвинутих країн не залишалася без пріоритетної уваги держави, а забезпечення громадян житлом - без державної допомоги. Характерно, що така увага корисна як державі (зміцнює iii економіку і стабільність), так і громадянам (підвищує їхній життєвий 
рівень). Навіть у розвинутих країнах більшість сімей не змогли б забезпечити собі нормальні житлові умови без підтримки через урядові програми.

Відомий науковець Ю. Габермас зазначив у одній зі своїх робіт [8], що соціальна політика дає змогу ліквідовувати крайні диспропорції і прояви незахищеності в суспільстві, при цьому розвинена система соціального захисту є політичним змістом сучасної масової демократії.

Сьогодні реалізація і формування державної житлової політики в Україні подекуди ототожнюється 3 реформою житлово-комунального господарства та розглядається у відповідних техніко-економічних термінах. При цьому, на жаль, ігноруються або замовчуються глибші соціальні наслідки в цій сфері.

Житлова політика має важливе соціальне та економічне значення. Існує низка економічних механізмів, що дають змогу скоротити витрати на вирішення житлової проблеми: зниження ставок рефінансування за житловими кредитами, надання пільг комерційним банкам, що беруть участь у державних житлових програмах, централізація системи страхування внесків на будівництво і купівлю житла, державне страхування на випадок втрати працездатності тощо. Проте економічні механізми не можуть замінити систему суто соціального впливу, пов'язаного з певним політичним курсом у процесі вирішення житлової проблеми, що передбачає, зокрема, комплексний перерозподіл прибутків у державі через прогресивне оподаткування, довгострокові кредити з пільговими відсотковими ставками для незаможних громадян тощо. 3 огляду на зазначене основною умовою соціальної ефективності житлової політики є глибокий і якісний аналіз соціальної стратифікації суспільства і основних потреб різних соціальних груп. Саме від цього залежить гнучкість і диференційованість житлової політики, що й дозволить забезпечити їі соціальну ефективність.

Висновки. У сучасних умовах держава має переходити до стимулюючого підходу, який передбачає наявність такої житлової політики, що забезпечує контроль i регулювання житлового сектора без прямого надання житла державою, а через надання державою підтримки (субсидії для громадян, пільгове оподаткування для забудовників тощо).

Обгрунтовано, що основною особливістю сучасної соціально орієнтованої житлової політики є принцип доступності.

Аналіз зарубіжного досвіду свідчить, що житлова політика $є$ одним 3 основних напрямів соціальної політики в сучасних умовах, оскільки вона значною мірою визначає якість життя на території не лише окремих міст, але і метрополій.

Оскільки житлова політика включає у себе не лише економічні, але, що більш важливо, і соціальні аспекти, iї ефективність слід розглядати не лише як економічну, але і як соціальну.

Україна потребує цілісної, всеохоплюючої житлової політики, яка даватиме відповіді на запитання: яким чином, через які механізми держава забезпечуватиме рівний захист права на житло для своїх громадян, на які програми мають право різні категорії громадян, якого результату 
заплановано досягти у визначеній перспективі.

\section{Лimepamypa:}

1. Постанова Пленуму Верховного Суду України "Про судову практику в справах про корисливі злочини проти приватної власності" від 25.12.92 р. N 12.

2. Словник синонімів української мови: у 2-ох т. - К.: Наук. думка, 2001. - Т. 1. C. $496-49$

3. Житловий кодекс Української РСР від 30.06.1983p. №5464-Х

4. В.I. Кравченко. Житлова економіка України: проблеми, теорії та практики. Інвестиції: практика та досвід DOI: 10.32702/2306-6814.2019.15.5

5. А. І. Шушківський. Житлова політика // Енциклопедія Сучасної України: електронна версія [веб-сайт] / гол. редкол.: І.М. Дзюба, А.І. Жуковський, М.Г. Железняк та ін.; НАН України, НТШ. Київ: Інститут енциклопедичних досліджень НАН України, 2006. URL: http://esu.com.ua/search_articles.php?id=19235

6. Постанова Верховної Ради України від 30 червня 1995 року №254/95-ВР

7. Олійник Наталія. Концептуальні засади державної житлової політики. - К.: Вісник національної академії державного управління при Президентові України, - 2010. №1, c.96-104

8. Habermas J. Theorie der Kommunikativen Handelns. Zur Kritik der funktionalistischen / J. Habermas. - Frankfurt am Main: Suhrkamp Verlag, 1985. - S. 504 - 522.

\section{References:}

1. Postanova Plenumu Verkhovnoho Sudu Ukrainy "Pro sudovu praktyku v spravakh pro koryslyvi zlochyny proty pryvatnoi vlasnosti" vid 25.12.92 r., № 12 [Resolution of the Plenum of the Supreme Court of Ukraine "On judicial practice in cases of mercenary crimes against private property" from 25.12.92, № 12]. zakon.rada.gov.ua. Retrieved from https://zakon.rada.gov.ua/laws/show/v0012700-92\#Text [in Ukrainian].

2. Slovnyk synonimiv ukrainskoi movy [Dictionary of synonyms of the Ukrainian language]. (2001). (Vols. 1). Kyiv: Nauk. dumka [in Ukrainian].

3. Zhytlovyi kodeks Ukrainskoi RSR : vid 30.06.1983 r., № 5464-X [Housing Code of the Ukrainian SSR from 30.06.1983, №5464-X]. zakon.rada.gov.ua. Retrieved from https://zakon.rada.gov.ua/laws/show/5464-10\#Text [in Ukrainian].

4. Kravchenko, V.I. (2019). Zhytlova ekonomika Ukrainy: problemy teorii ta praktyky [Housing economy of Ukraine: problems of theory and practice]. Investytsii: praktyka ta dosvid - Investments: practice and experience, 15, 5-12 [in Ukrainian].

5. Shushkivskyi, A.I. (2006). Zhytlova polityka [Housing policy]. Dziuba, I.M., Zhukovskyi, A.I., Zhelezniak, M.H., et al. (Eds.). Entsyklopediia Suchasnoi Ukrainy Encyclopedia of Modern Ukraine. Kyiv: Instytut entsyklopedychnykh doslidzhen NAN Ukrainy. Retrieved from http://esu.com.ua/search_articles.php?id=19235 [in Ukrainian].

6. Postanova Verkhovnoi Rady Ukrainy "Pro Kontseptsiiu derzhavnoi zhytlovoi polityky" : vid 30 chervnia 1995 roku, \#254/95-VR [Resolution of the Verkhovna Rada of Ukraine "On the Concept of State Housing Policy" from June 30 1995, №254/95-BP]. zakon.rada.gov.ua. Retrieved from https://zakon.rada.gov.ua/laws/show/254/95$\%$ D0\%B2\%D1\%80\#Text [in Ukrainian].

7. Oliinyk, N. (2010). Kontseptualni zasady derzhavnoi zhytlovoi polityky [Conceptual principles of state housing policy]. Visnyk natsionalnoi akademii derzhavnoho upravlinnia pry Prezydentovi Ukrainy - Bulletin of the National Academy of Public Administration under the President of Ukraine, 1, 96-104 [in Ukrainian].

8. Habermas, J. (1985). Theorie der Kommunikativen Handelns. Zur Kritik der funktionalistischen. Frankfurt am Main: Suhrkamp Verlag [in German]. 